Archives de sciences sociales des religions

127 | juillet - septembre 2004

Max Weber, la religion et la construction du social

\title{
The Approach of Max Weber's Sociology of Religion as Exemplified in His Study of Ancient Judaism
}

\section{Wolfgang Schluchter}

\section{(2) OpenEdition \\ 1 Journals}

Electronic version

URL: http://journals.openedition.org/assr/2380

DOI: $10.4000 /$ assr.2380

ISSN: $1777-5825$

Publisher

Éditions de l'EHESS

\section{Printed version}

Date of publication: 1 July 2004

Number of pages: $33-56$

ISBN: 2-222-96751-1

ISSN: 0335-5985

\section{Electronic reference}

Wolfgang Schluchter, "The Approach of Max Weber's Sociology of Religion as Exemplified in His

Study of Ancient Judaism », Archives de sciences sociales des religions [Online], 127 | juillet - septembre 2004, Online since 25 June 2007, connection on 10 December 2020. URL : http://

journals.openedition.org/assr/2380; DOI : https://doi.org/10.4000/assr.2380 


\section{THE APPROACH OF MAX WEBER'S SOCIOLOGY OF RELIGION AS EXEMPLIFIED IN HIS STUDY OF ANCIENT JUDAISM}

\section{Preface}

Max Weber's study of ancient Judaism, on which he worked after 1910, is particularly well-suited to shedding light on the approach of his mature sociology of religion, with its comparative and developmental orientation. This is particularly the case if systematic questions and those bearing on the history of his works are linked. Having devoted himself from the very beginning of his career to 'Mediterranean' antiquity, he was naturally familiar from early on with aspects of the history of Israelite-Jewish religion. However, this knowledge did not find literary expression in his work till 1910. Neither in "The Protestant Ethic and the 'Spirit' of Capitalism" of 1904-1905 nor in his study on the "Agrarian Conditions in Antiquity" of 1909 we find more than sporadic remarks on the history of Israelite-Jewish religion. This can scarcely be mere chance. It is much more plausible to conjecture that Max Weber was not working intensively on the history of Israelite-Jewish religion until the period from 1910 onwards. For even in the "Replies to Critics", which resulted from the Fischer-Rachfahl debate, following the publication of the "Protestant Ethic", ancient Judaism does not play a major role. And the last "Reply" appeared in 1910. Admittedly, it was not Weber's intention to give a history of the religion of antiquity in the "Agrarian Conditions", nor was the further prehistory of ascetic Protestantism a subject of controversy in the Fischer-Rachfahl debate, so that no discussion of ancient Judaism from the point of view of religious history should be expected in these writings (1). But even if these texts are not

(1) In the "Agrarian Conditions", Weber analyzes the capitalism of antiquity as a system and relates it to ancient forms of state organization. He does not take an interest in religions and their consequences on economic attitudes. In the "Replies", his concern is the defence of the original thesis of the study on Protestantism. Weber does indicate in various places that he intends to 'extend' his investigations forward and backward, and indeed in his final reply to the critiques of the "Protestant Ethic" of 1910 there is even mention of a projected return to ancient Christianity, though not to ancient Judaism. Cf. Max Weber, Die protestantische Ethik II. Kritiken und Antikritiken, pub. by Johannes Winckelmann, 4th ed., Gütersloh, Gerd Mohn, 1982, p. 322. 
taken as "testimony" that the writer 'was not working' on the religious history of ancient Judaism, there is plenty of evidence that actually it was only after 1910 that, in connection with Max Weber's now awakened interest in Asian religions, he was also more specifically examining the history of Israelite-Jewish religion. This eventually came to fruition with his study Ancient Judaism, that from the start encompassed the whole spectrum from ancient Israel to early Christianity (2).

I shall deal with my theme in four steps: I shall start by saying something about the major projects, which were complementary, though not executed simultaneously, on which Max Weber was working from 1910 until his death, and which both remained unfinished. These were his Grundriss article, known under the title Economy and Society, and the Gesammelte Aufsätze zur Religionssoziologie: comparative studies on the economic ethics of world - or rather cultural - religions [1] (3). There follow reflections on the unconventional combination of comparative and developmental viewpoints which underlies his reconstitution of major processes in religious history [2]. I shall then show that he takes the creations of the Old Testament, the Bible of the Jews, as the "turning point" - one might even say the point of departure - for one of these great processes in religious history, the development of the Israelite-Jewish-Christian and Islamic religions [3]. Finally, I shall consider whether it is tenable to designate the ancient Jews as a pariah people which, from the "forcible internment" (4) onwards, that is to say, from the Babylonian exile until the fall of the second Temple, voluntarily brought itself into this situation. Max Weber's formula on the subject: from a political to a confessional community.

\section{The uncompleted major projects}

It is known that Max Weber's scholarly writings from 1910 until his death dealt with two major projects, which gradually became distinct and then developed separately: his contribution to the Handbuch der politischen Oekonomie, later entitled Grundriß der Sozialökonomik, which he called first "Economy and Society", then "The Economy and the Societal Orders and Powers" and finally, it seems, "Sociology" (in the following: his Grundriss article); and his "material economic cultural sociology" (5), the core of which should be sought in the Essays in the

(2) This choice of title is far from self-explanatory, and signals a special approach to the topic.

(3) The title does indeed specify world religions, but Weber says expressly that Judaism is not a world religion, but rather a cultural religion. For the distinctions between the concepts of cultural, world and redemptive religions, see Wolfgang Schluchter, Religion und Lebensführung, 2 vols, Frankfurt, Suhrkamp, 1988, here vol. 2, pp. 24ff.

(4) WeBER, 1920 , p. 4 (hereafter: $R S$ III). Weber even goes so far as to assert that voluntary ghetto life had existed "long before forcible internment".

(5) This quotation is taken from the "Preface" to the publication of the 1 st part of the Grundri $\beta$ der Sozialökonomik, dated 2nd June 1914. The "Preface" is written by Max Weber. The choice of words 'material economic cultural sociology' certainly seems strange. 'Material' is indeed comprehensible in this context, as Weber was trying in his Grundriss article to disregard the relationship of economics to the particular elements of cultural content, among which he mentions "literature, art, science etc." (Max 
Sociology of Religion ("Religionssoziologische Skizzen"), later entitled "Comparative Essays in the Sociology of Religion", part of it being "The Economic Ethics of World Religions" ("Vergleichende religionssoziologische Versuche"). He originally intended to publish these essays together with his Grundriss article. As this was prevented by the outbreak of war, he published them separately from 1915 onward in the Archiv für Sozialwissenschaft und Sozialpolitik. Finally he wanted to publish them as Gesammelte Aufsätze zur Religionssoziologie, in combination with earlier texts, some of them revised, some extended, together with unpublished essays mostly still to be written. The first volume of this gigantic undertaking appeared in 1920. Part of this project was the study on ancient Judaism, which he first had presented from October 1917 onwards as a sort of 'serial novel' in the Archiv für Sozialwissenschaft und Sozialpolitik(6). But there was to be a revised version of the Gesammelte Aufsätze. Like the Grundriss article, which breaks off all too soon, the collection ends prematurely with the revised "Intermediate Reflection", which leads on to the religions of India. Of the four volumes Weber anticipated, only the first one was published with his authorization.

The first fact to bear in mind is that Weber's "material economic cultural sociology", in which I include the essays in the sociology of religion ("Religionssoziologische Skizzen"), was originally to appear as a supplement to the Grundriß der Sozialökonomik together with his article "The Economy and the Societal Orders and Powers". This is shown by the "Preface" to the Grundri $\beta$ taken in conjunction with the footnote that accompanies the separate publication of the essay in the sociology of religion dealing with Confucianism in October 1915. "The first parts", Weber writes here, are published "unaltered, just as they were written down and read to friends two years ago." And he adds that the essays were originally meant to appear simultaneously with his Grundriss article, in order to "inter-

(note 5 continued)

Weber-Gesamtausgabe (MWG) I/22-1, p. 114). What 'economic cultural sociology' may be, however, is less clear. It must either be an analysis of culture from an economic standpoint, or else a sociology of culture. This remarkable conceptual definition could, though, be the expression of Weber's intention of emphasizing the importance of each side of the causal relationship to both his theoretical and historical ponderings, that is to say the economic conditioning of 'culture' as much as the cultural conditioning of the economy. More will be said on this later. This would then lead to an economic sociology of literature, an economic sociology of art, etc. However this may be, possible candidates for this "material economic cultural sociology", apart from studies in the sociology of music, which already existed at this stage, include the essays in the economic ethics of world religions. As the footnote of 1915 in the Archiv shows, these were obviously alluded to with the rest. On the "Preface" and other documents relevant to reconstructing the history of the emergence of the major projects, see the compilation of Johannes Winckelmann, Max Webers hinterlassenes Hauptwerk: Die Wirtschaft und die gesellschaftlichen Ordnungen und Mächte. Entstehung und gedanklicher Aufbau, Tübingen, J.C.B. Mohr (Paul Siebeck), 1986, here, p. 165, and for an overall view, Wolfgang ScHLUCHTER, Individualismus, Verantwortungsethik und Vielfalt, Weilerswist, Velbrück Wissenschaft, 2000, pp. $179 f f$.

(6) Max Weber starts the publication of the essays in ancient Judaism in October 1917 with a footnote that deserves attention, clarifying his further plans: "The following presentation (of ancient Judaism, W. S.) is published here omitting the discussion of the Egyptian, Babylonian and Persian conditions. In a future collection and revised publication (for China, provided with source references and revised), in combination with other earlier essays, some of them unpublished, the missing part will be inserted". Cf. Archiv für Sozialwissenschaft und Sozialpolitik, Volume 44 (1917/1918), p. 52. As Weber never got as far as to ancient Judaism when compiling the Gesammelte Aufsätze zur Religionssoziologie, the omitted discussion of the Egyptian, Babylonian and Persian conditions still remained unpublished, possibly unwritten. Nevertheless, comparative references to these conditions occur repeatedly in the study itself. 
pret and supplement the section on the sociology of religion (though also to be interpreted by the latter on many points)." (7) This "section", however, was not available to the scholarly public at the time. Presumably also written down in 1913 (8), it considers, under the title "Religious Communities", on the one hand the class conditioning of religions, and on the other hand the connection between cultural religion and economic attitudes. Weber had already expounded the latter relationship in his study on ascetic Protestantism. Now he is not only pursuing both interrelations, but he also includes all the cultural religions that he considers important, in addition to ascetic Protestantism, Confucianism, Hinduism, Buddhism, Judaism, Early Christianity and Islam. They form the material for defining concepts and for obtaining regularities, 'laws', as well as their qualification. As already stated, the outbreak of the war prevented the publication of the Grundriss article and the essays at the same time. The section on "Religious Communities" was left for revision until after the war(9). Even during the recasting of the Grundriss article in the years 1919/1920, it remained untouched. While Weber continued to work on his essays from 1916 onward, we may suppose on the basis of the old manuscripts, the sociology of religion section of the Grundriss article remained unaltered. This was not in accordance with his plans, as we learn from the "Preliminary Remarks" ("Vorbemerkung") to the first volume of the Gesammelte Aufsätze zur Religionssoziologie that he had submitted for printing. He had still not been able, he writes there, to use the ethnographic-folkloristic material adequately for his approach to the sociology of religion. And he goes on: "I hope to be able to do something [to rectify this omission] during a systematic treatment of the sociology of religion. (10)" This hope, however, turned out to be in vain.

The sociology of religion contained in the Grundriss article remained in the state of 1913, but the historically oriented essays in the Sociology of Religion of 1913 were taken further. Thus the two major projects did not develop simultaneously. The knowledge gained in the essays was no longer put to use in the chapter on the sociology of religion in the Grundriss article. Of course, this does not alter the complementarity of the two major projects. One could even say that this made it possible for Max Weber to strive for this complementarity with even greater effectiveness. For while Max Weber was seeking to broaden the essays by extending the studies on Protestantism to studies on Confucianism and Taoism, Hinduism, Buddhism and, via ancient Judaism, on Talmudic Judaism, Early Christianity, Oriental Christianity, Islam and Occidental Christianity, he was endeavouring to condense the Grundriss article, on the basis of the pre-war manuscripts and in the light of new insights. How this was to be achieved, we can see

(7) Archiv für Sozialwissenschaft und Sozialpolitik, Volume 41 (1916), p. 1. Weber used this expression again in the Gesammelte Aufsätze zur Religionssoziologie. He simply changed "two years ago" to "two years before". Cf. Max WeBER, Gesammelte Aufsätze zur Religionssoziologie, Tübingen: J.C.B. Mohr (Paul Siebeck) 1920, p. (hereafter RS I) und MWGI/19, p. 83. Where an edition of Max Weber Gesamtausgabe is available, quotations are also referenced to this.

(8) On this subject, see also the editorial report of Hans G. Kippenberg in MWG I/22-3, pp. 89.

(9) This is not quite true, as Weber got out the manuscript at least once more, to use it as the basis for a lecture at the University of Vienna in the summer term of 1918. This was a sort of probationary term that he had insisted on, to see whether he could accept the invitation to succeed Eugen von Philippovich. Weber then declined this offer. See also MWG, I/17, p. 12.

(10) $R S$ I, p. 15. 
from the two editions of the "Sociology of Domination": the pre-war version, in the layout of the Grundriß der Sozialökonomik, takes up about 200 pages, while the post-war version as submitted by Weber for printing has been compressed into about 50 pages.

For the Gesammelte Aufsätze zur Religionssoziologie we are in possession of a plan sent by Weber to his publisher Paul Siebeck in 1919 and which he followed in the preparation of the first volume. However, we have no comparable plan for the projected new version of the Grundriss article. One thing is clear, though: in his work on the Grundriss article in 1919/1920, Weber no longer adhered to the table of contents of "The Economics and the Societal Orders and Powers" to be found in 1914. According to this table of contents, the complete analysis was to culminate with the sociology of domination, with which he intended to make the transition from structure to process (11). This idea is now given up, the sociology of domination is now placed after the economic sociology, but before "Class and Status" and before the sociology of communities, religion, law and the (modern) state. As previously remarked: The revision of the sociology of religion, unlike the sociology of domination, was never carried out. Indeed, with the exception of the remark quoted above, there is also no indication of how he had planned this revision. For the construction of the chapter on religion in the Grundriss article, the only evidence that has come down to us is the table of contents and the manuscripts from the time before the war; for the Gesammelte Aufsätze zur Religionssoziologie, on the other hand, a later plan exists. (On this subject, see Appendix A and B.)

Although the development of the two major projects was not simultaneous, their complementarity was conserved. The reason for this is not merely pragmatic, but also methodological. Max Weber's conception of his Grundriss article was meant to achieve a "coherent sociological theory and exposition", as he expressed it in a letter to his publisher Paul Siebeck in December 1913, while the essays in the sociology of religion, written in 1913, were meant as historical investigations. "Theoretical constructions with illustrative use of the empirical - historical investigation with use of theoretical concepts as the ideal borderline cases", was the way that, as early as 1904, in the essay on objectivity, he had defined the relationship between the theoretical and historical perspective in economics (12). This definition is used again in the "Basic Sociological Terms" which serve to introduce the new Grundriss article and are applied in general to the relationship between sociology and historiography: Sociology, he says here, creates type-concepts and seeks

(11) In this connection, cf. in particular MWG I/22-2, p. 114. This passage is especially important in clarifying the original objectives of the Grundriss article. Weber expressly emphasizes that what matters to him is "a general analysis, taking the particular only by way of examples". He intended to discuss only the "general forms of structure of human communities". And further: "The content-related directions of community action are only taken into consideration insofar as they generate forms of structure which are specific in nature and at the same time economically relevant. The limit thus defined is no doubt extremely fluid, but invariably means that only a few highly universal varieties of community are examined. In what follows, this is done first only with regard to general characteristics, whereas - as we shall see - it will only be possible to discuss their forms of development with some degree of precision at a later stage, in connection with the category of 'domination'."

(12) Max Weber, Gesammelte Aufsätze zur Wissenschaftslehre, Tübingen, J.C.B. Mohr (Paul Siebeck), p. 205 (hereafter: $W L$ ). 
for regularities governing events, while historiography, in contrast, aims at "causal analysis and the explanation of individual actions, patterns, personalities of cultural significance" (13). And for this purpose, one might add, a comprehensive sociological theory should be useful. Nevertheless, Weber does not seek primarily to determine the relationship of disciplines, but to clarify a scientific stance that employs both perspectives, an approach that he himself practised. The study on ascetic Protestantism of 1904-1905 was already an example, as far as he was concerned, of a historical investigation, in particular a religious-historical investigation. The essays in the sociology of religion, written in 1913 and continued from 1915 onward, are the same.

Yet the subtitle, essays in the sociology of religion, not on the history of religion, which later were even described as comparative essays in the sociology of religion, certainly seems to contradict this interpretation. Is sociology, to Weber, not primarily a generalizing social science? There is no doubt that it is, just as to him economics represent a generalizing social science, both being cultural sciences (14). But as in economics, this is not denied by the distinction between the theoretical and historical perspective within a single discipline. "Not the 'material' relationships of 'things', but the intellectual relationships of problems", in Weber's words, constitute the foundation of scientific works. On the basis of the "specific viewpoints, from which light may be shed on the meaning of given cultural elements", the distinction between disciplines will be engendered (15). Thus the analysis of cultural reality is necessarily one-sided, and this one-sidedness is not only logical, but also pragmatically justified, because the "schooling of the eye to observe the operation of qualitatively similar categories of causes and the constant application of the same conceptual apparatus [provides] all the advantages of the division of labour" (16). But the disciplinary commitment to a specific viewpoint does not invalidate the logical distinction between the theoretical and historical approach. Indeed, for a long time Weber hesitated to characterize his approach as sociological, because he feared that he might be misunderstood as seeking to overcome the necessarily one-sided analysis of cultural reality from a special viewpoint by a general social science which would eliminate this distinction. This he considers to be impossible on logical grounds. For this reason he first expressly acknowledges the fruitfulness of a socio-economic analysis of cultural reality. For, to quote the essay on objectivity: "Liberated from the outdated belief that all cultural manifestations can be deduced as the product or function of 'material' interests, we on our part believe, on the contrary, that the analysis of social manifestations and cultural processes from the special viewpoint of their economic conditioning and consequential scope was a scientific principle of creative fruitfulness and, applied with care and an absence of dogmatism, will remain so for all the foreseeable

(13) Max Weber, Wirtschaft und Gesellschaft, 4th ed., Tübingen: J.C.B. Mohr (Paul Siebeck) 1956, p. 9 (hereafter. $W u G$ ).

(14) In the essay on objectivity, it is stated: "If we decide to give the name of 'cultural sciences' to such disciplines that observe the processes of human life from the point of view of their cultural significance, then social science in our sense is included in this category." Cf. Max WEBER, WL, p. 165. In his lectures at the turn of the century, Weber was already terming economics a social science.

(15) Ibid., p. 166.

(16) Ibid., p. 170. 
future. (17)" But parallel to this statement, he also wrote a study that was specifically based, not on the economic conditioning of religious manifestation, but on the religious conditioning of economic manifestations, examining phenomena which specifically do not fall within the compass of an economic viewpoint, even if, in the context of an economic approach, a distinction is made between economic, economically conditioned and economically relevant (18). For economically relevant phenomena are first and foremost non-economic in nature. And for this reason, Weber is primarily concerned in this study to employ a "conceptual-methodical apparatus" which departs from that of socio-economics, and to present a causal attribution which, in a complicated manner, links hopes of salvation and their religious significance with economic attitudes. Here he also intended to show how ideas can operate in history, specifically as factors of conditioning and not always as factors conditioned, as postulated, for example, by historical materialism "as the common denominator in a causal explanation of historical reality" (19). But even if we abstain from such a 'Weltanschauung' and content ourselves instead with an "economic interpretation of history" (20) we have still to take the non-economic factors of historical life into consideration. From an economic viewpoint, we are concerned with (rational) action under conditions of material scarcity in the battle with nature and with other people. True, from a religious viewpoint, this is also our concern (material and ideal interests), but not this alone. Here the focus is rather on the question of meaning, the question of one's own destiny of salvation, and the scientific reply to this question requires an interpretation of history which is not only economic, but also 'spiritual' (21). Sociology is therefore a discipline which,

(17) Ibid, p. 166. In this connection, it should not be forgotten that the purpose of Weber's essay, in addition to the aims of the new Archiv für Sozialwissenschaft und Sozialpolitik, was to emphasize continuity with its predecessor, the Archiv für soziale Gesetzgebung und Statistik. The latter, however, had "treated the topics that it dealt with as socio-economic matters, right from the start." Ibid., p. 161.

(18) This Weber did, as is known, in his essay on objectivity, though here he was to extend the scope of the socio-economic approach beyond the bounds of the permissible. Cf. ibid., p. 162. It immediately becomes clear that this approach in particular is not sufficient to encompass the religious conditioning of such economic manifestations as the 'spirit' of modern capitalism, since for this purpose, to employ a subsequent formulation, seen from the economic viewpoint, the other side of the causal relationship is important. Also, in his distinction between the economic, the economically conditioned and the economically relevant, strictly interpreted, Weber does not speak at all of a socio-economic approach, and thus of the specific viewpoint of the analysis, but only of socio-economic problems. In my view, it is therefore erroneous, to define Weber's approach in 1904 and thereafter as socio-economic. In reality, even the study on ascetic Protestantism definitely does not fit this designation. For "the processes of daily life, no less than the 'historic' events of high politics, collective and mass manifestations as much as the 'unique' acts of statesmen or individual literary and artistic achievements are simultaneously influenced by [material interests, Wolfgang Schluchter (W.S.)], - 'economically conditioned'. On the other hand, the totality of all the manifestations and conditions of life of a given historical culture exert an influence on the form of material needs, the way in which they are satisfied, the formation of material interest groups and the type of their power resources and thence on the type of process of 'economic development' - it becomes 'economically relevant'." $W L$, p. 163. It is also true that the distinction between the economic, the economically conditioned and the economically relevant can be transferred in an analogous way to all value spheres and life orders, and to all the regulations and powers of society. Thus cultural manifestations may be religious, religiously conditioned or religiously relevant.

(19) Ibid., p. 166.

(20) Ibid., p. 167.

(21) Cf. in this connection $W L$, pp. $166 f$. It was not by chance that Weber, in a letter to Rickert, described his procedure in the Protestantism study as a 'kind of spiritual construction of modern economics'. 
like economics, sheds light on social manifestations and cultural processes from specific, and thereby necessarily one-sided viewpoints, and develops a conceptualmethodical apparatus to this end. This is exactly what Weber does in his contribution to the Handbuch der politischen Ökonomie, later entitled Grundriß der Sozialökonomik, but already in his dispute with Rudolf Stammler, which is the basis of the latter work. The dominant viewpoint for sociology is the interaction of economic and non-economic factors in different value spheres and life orders: the economy and economic powers in their relation to the other societal orders and powers are at issue, and these relations are to be examined from a theoretical and a historical point of view.

This leads me on to my second step. I have given it the heading: "Comparison and Developmental history". How does this heading fit into our deliberations so far?

\section{Comparison and Developmental History}

First of all, there can be no doubt that the primary purpose of Weber's revised Grundriss article of 1919-1920 is to establish sociological concepts and to determine regularities, 'laws' of social life. This is not the case in the studies on the economic ethics of world religions, where sociological concepts and regularities are applied. This pronouncement is in no way invalidated by the fact that both the major projects are based to a considerable extent on the same material. Indeed, Weber expressly states that sociology draws "its material, as paradigms, very largely, though by no means exclusively, from the realities of action which are also relevant from historical viewpoints." It constructs its concepts and seeks rules "above all also from the point of view of whether it can thus be of service to the historical causal attribution of manifestations of cultural significance." And he goes on: "As in every generalizing science, the peculiarity of its abstractions dictates that its concepts with respect to the concrete reality of historical fact must be relatively empty of content. What it has to offer in exchange is the enhanced precision of concepts. (22)" In this sense, the three pure types of legitimate domination taken from the revised Grundriss article with respect to the concrete reality of historical rulership are concepts relatively empty of content, while the description of the structure and culture of Chinese patrimonial bureaucracy in the study on Confucianism (and Taoism) is relatively full of content by comparison.

In the Gesammelte Aufsätze zur Religionssoziologie too, we certainly find passages which serve concept formation rather than their application; the "Preliminary Remarks" ("Vorbemerkung"), the "Introduction" ("Einleitung") or the "Intermediate Reflection" ("Zwischenbetrachtung") come to mind, as these passages all adhere closely to the Grundriss article; in fact they are extracts from "Religious Communities" (23). They introduce and then lead on to the "causal analysis and

(22) Max Weber, $W u G$, pp. $9 f$.

(23) The "Introduction" und "Intermediate Reflection", in particular, are pre-formulated in the "Religious Communities" section of the Grundriss article of 1913. See Wolfgang Schluchter, Religions und Lebensführung, 1988, II, p. 576. 
explanation of individual actions, patterns and personalities of cultural significance" (24). This is finally also made clear in the "Preliminary Remarks", written in 1919-1920, to the Gesammelte Aufsätze zur Religionssoziologie. Here it is stated that the collection is intended to help to "identify the specific character of occidental rationalism, and within it, of modern occidental rationalism, and to explain its origin" (25). Weber requires of himself then, from the point of view of method, a historical investigation in logical terms, undertaken from a sociological viewpoint. The study on ascetic Protestantism had already been just such a historical investigation. And the study on ancient Judaism is another one.

It is certainly not possible to interpret Weber's switch from the theoretical to the historical viewpoint as a lapse into narration in historiography. The Gesammelte Aufsätze zur Religionssoziologie are also attempts at a comparative sociology of religions, because they not only have a problem of identification to solve (recognition of the specific character of the manifestation), but are also conducted from a sociological viewpoint. Specifically, the concern here is with both sides of the causal relationship, as already set out in the Grundriss article of 1913: the class conditioning of religion on one hand, the religious conditioning of economic attitudes on the other. These two sides of the causal relationship must be comparatively delineated, but made plain from a historical viewpoint (individualizing, not generalizing concept formation !). To this extent too, the Grundriss article and the essays in the sociology of religion are complementary. The first work pursues these two relationships from a theoretical viewpoint, through generalizing concept formation, the second from a historical one, through individualizing concept formation. And the fact that both sides of the causal relationship are now pursued in the "Economic Ethics of World Religions" distinguishes them from the study on ascetic Protestantism, but does not alter their historical caliber. For Weber expressly states that in the study on ascetic Protestantism he only dealt with one side of the causal relationship, the "conditioning of the emergence of an 'economic ethic': the 'ethos'; of an economy by the specific content of the religious creed". In the studies on the economic ethics of world religions, however, he deals with both sides of the causal relationship, that is to say that he includes also the other side that had been voluntarily left in parentheses in the study on Protestantism. As he formulates it with all the clarity that could be desired: "The later (with respect to the study on Protestantism, W. S.) essays on the 'Economic Ethics of World Religions' attempt, in an overall view of the relationships of the most important cultural religions to the economy and to social class, to investigate both sides of the causal relationship in whatever depth may be necessary to find points of comparison with the occidental development still to be analysed (26)."

Thus Weber certainly did not understate the difference between the studies on ascetic Protestantism - the 1904/05 study was supplemented in 1920 and now enriched with the almost entirely new essay on the Protestant sects - and the studies on the economic ethics of world religions. This can also be detected with very little difficulty from the "Table of Contents", authorized by himself, of the first volume of the Gesammelte Aufsätze zur Religionssoziologie. According to this, the 
"Preliminary Remarks" written in 1919-1920 applies to all the essays, i.e. including the revised version of the "Protestant Ethic" and the essay on the "Protestant Sects"; the "Introduction" and "Intermediate Reflection", on the other hand, apply only to the "Economic Ethics of World Religions", notwithstanding the fact that all previously published texts were revised. Indeed, the conceptual apparatus that had been developed since 1904-1905 is used throughout; in the essay "The Protestant Ethic and the Spirit of Capitalism" - spirit now without quotation marks -, this is especially true of the insertions, which, as elsewhere, are the primary constituent of the revision. (See Appendix C) (27).

The primary function of comparisons is to identify peculiarities, not to explain them (28). Furthermore, they serve to construct sociological concepts. As the construction of concepts is not central to the essays on the economic ethics of world religions, the principal use of comparisons here is to determine the specific characteristics of occidental cultural manifestations. As the above quotation shows, Weber wishes to pursue Asiatic cultural manifestations only insofar as it is necessary "to find points of comparison with the occidental development still to be analysed." We could rephrase this: In this way, the difference characteristic of occidental development compared with Asian developments will be identified. Once this has been done, it will be known what "crucial turning points" await clarification. With respect to religious history, it is not only the turning point related to ascetic Protestantism. More relevant are the turning points that arose before and after. The subsequent phenomenon that Weber wanted to examine was the CounterReformation. For the preceding turning points, Weber gives the decisive indication in the revised edition of the study on ascetic Protestantism: "That great process in religious history of the disenchantment of the world, which started with the prophets of ancient Judaea, and, in combination with Greek scientific thought, rejected all magical means of seeking salvation as superstition and sin, reached its conclusion here (in ascetic Protestantism, W.S.) (29)."

In 1904-1905, in the first version of the study on Protestantism, Weber had not yet spoken of a great process of disenchantment of the world in religious history, (30) nor of the significance of the "Hellenic intellectual culture", the Pauline

(27) This applies especially to the concepts of asceticism and mysticism.

(28) This formulation needs some qualification, however, in that comparisons naturally also play a role in causal attribution, as any experiment with a control group will show. Even thought experiments obey the same logic. And it is not by chance that John Stuart Mill recommended the method of differences to the 'moral sciences'. Nevertheless, comparison and causal attribution are two different things.

(29) Ibid., pp. $94 f$.

(30) Even in the first version of the study on Protestantism, however, Weber draws already attention to the affinity between Palestinian Jewry and English Puritanism, also known with some justification as "English Hebraism", for the latter shows a tendency "to treat the pronouncements of the Bible "like paragraphs of a book of law" (ibid., p. 179), and therefore to disseminate the spirit of "formal legality", of "self-righteous, sober legality". Yet this spirit cannot be traced back precisely to the "time of writing of the Old Testament scriptures", but to Jewry, "as it gradually evolved under the influence of many centuries of formalistic-legal and Talmudic education" (ibid., p. 181). Among the canonical scriptures, he mentioned in this connection only the book of Job, and in the Apocrypha, the book of Ecclesiasticus, thought to date from the beginning of the second century BC. This last, however, is linked to German Pietism, not to English Puritanism (cf. ibid., pp. 179f.). There is as yet no mention, though, of the creation of the Old Testament, the role of the Levites and the Prophets, or even of voluntary ghetto existence, the pariah-people condition. These links are not established until the second version of the essay. 
mission, Roman law, "the Roman church resting on the Roman concept of office" or the "medieval order of estates" for the emergence of modern rationalism (31). All this he includes now in the occidental development still to be analysed. Of course, one can only comprehend the perhaps decisive turning point that caused differences by going back to the "creation of the Old Testament". Part of this creation, however, is ancient Jewish prophecy, especially prior to the Exile (32).

The differences linked to these cultural manifestations point in one and the same direction: a "religious ethic of innerworldly conduct which is highly rational, that is to say free from magic and all forms of irrational striving for salvation" (33). Seen from the point of view of religious history, this is a development which deviates from those prevailing in Asia. This becomes clear to Weber in his "extremely superficial tour of the world of Asiatic culture" (34). For Asiatic developments are not favourable to the shaping of a religious ethic of rational innerworldly conduct. Weber formulates his position on this question in the summary of his studies on Confucianism and Taoism, Hinduism and Buddhism as follows: "Wherever a higher stratum of intellectual strives to fathom the 'meaning' of the world and its own life by reflection, and - after the failure of this strictly rationalist endeavour to comprehend this through experience and then raise this experience indirectly by rationalistic means into its consciousness, the way will somehow lead into the silent hidden realm of Indian indefinable mysticism. And where, on the other hand, a higher stratum of intellectual, rejecting these attempts to flee the world, instead consciously and deliberately finds the highest possible goal of inner fulfilment in the grace and dignity of a beautiful gesture, it will somehow arrive at the Confucian ideal of nobility. But a significant part of all Asiatic intellectual culture is composed of a mingling and interweaving of these two constituents. The concept of merely acting in accordance with the 'challenge of the day' to achieve that relationship with the real world which is at the heart of the whole specifically occidental sense of 'personality', remains as remote from it as the purely impersonal rationalism of the West, which seeks to master the world through practical means by discovering its own impersonal system of laws (35)."

The occidental development so far analysed and to be further analysed by Weber therefore requires a developmental-historical viewpoint of broad scope. Development means to him neither undirected change nor progress. When Friedrich H. Tenbruck, who otherwise distinguishes pertinently between religious-historical disenchantment and modernization embracing secularization, opines that Weber has thus switched his allegiance to the camp of the classical evolutionists, the misunderstanding could not be more profound (36). Weber espouses no theory of inclusive steps, such as that presented in Hegel's evolutionary model (37). Neither does

(31) E.g. the enumeration in $R S$ III, p. 7.

(32) Cf. in this connection RS III, pp. $6 \mathrm{f}$.

(33) Ibid. p. 6.

(34) E.g. $R S$ II, p. 363 (MWG I/20, p. 526).

(35) $R S$ II, p. 377 (MWG I/20, pp. 542f.).

(36) Friedrich H. TenBruck, "Das Werk Max Webers", Kölner Zeitschrift für Soziologie und Sozialpsychologie, 27, 1975, pp. 703ff.

(37) Cf. for further details the preface to the paperback edition of my book Die Entstehung des modernen Rationalismus. Eine Analyse von Max Webers Entwicklungsgeschichte des Okzidents, Frankfurt, Suhrkamp 1998, pp. 25ff. 
he simply follow Darwin's theory of evolution, although in terms of logic, he comes close to it. His concept of development is conditionally teleological in form, requiring constructs of value-related ideal types. These are heuristic means for causal attribution. At issue is always a particular developmental history whose reconstruction requires three steps: identification (What is the defining characteristic of a cultural manifestation?), causal attribution (How did this manifestation arise?) and prioritization (What weight can be attributed to one causal factor in relation to other causal factors?) (38). The first question can only be answered by means of comparisons, the second and third only by counterfactual arguments using the categories of objective possibility and adequate causation, as Weber develops them with reference to von Kries and Radbruch (39). Here he rightly stresses that the problem of prioritization in historical processes - the key to judging between adequate causes - can mostly not be settled, or in any case only with difficulty. When all this is borne in mind, it becomes easy to understand why he included the following remark into his plan for the Gesammelte Aufsätze zur Religionssoziologie in 1919: "The issue everywhere is how to handle the question of what is the foundation of the economic and social defining characteristic of the Occident, how it arose and, in particular, how it stands in relation to the development of the religious ethic (40).”

Thus in his historical investigations, Weber describes the religious developmental history of cultures without becoming entangled in the coils of classical evolutionism. His studies on the logic and methodology of the social sciences as cultural sciences aim to separate two pairs of questions: the question of the relevance of a phenomenon from that of its validity, and the question of development from that of progress. For both these distinctions, it was Heinrich Rickert who had laid the logical groundwork. A prerequisite for the first separation is to be able to distinguish between theoretical value relatedness and practical evaluation; the second demands the capacity to distinguish a conditional-teleological construction from a mere sequence of changes on the one hand and from progress on the other. From the point of religious history, there are thus, as Weber sees it, a number of culture-bound developmental histories, each having its own origin, from which, with the passage of time, lines branch out, but also intersect and under certain circumstances even merge: the Confucian-Taoist, the Hindu-Buddhist and the "Israelite-Jewish-Christian religious development", of which the Islamic religious development is a later descendant (41).

Weber deals with these religious developmental histories asymmetrically. As the quotation cited above makes clear, he is interested in Asia only insofar as it

(38) The proposition that a consequence can have more than one cause is a commonplace that should not be ascribed to Max Weber. Some Weber interpreters see this 'realization' as his greatest achievement. If this were so, it would hardly be worth giving him any attention today. He did indeed have most sophisticated concepts of causality and attribution. To understand this, one need only read his remarks on "objective possibility and adequate causation in the consideration of historical causality", in which, admittedly, he did not achieve absolute clarity. See also WL, pp. 266-290. and Gerhard WAGNER, Heinz ZiPPRIAN, "The Problem of Reference in Max Weber's Theory of Causal Explanation", Human Studies, 9,1986, pp. 21-42

(39) In this connection see $W L$, pp. 271-277.

(40) News bulletin. 11.

(41) Cf. RS III, p. 2 Fn. and p. 7. 
provides points of comparison for the occidental religious development which is to be further analysed. Judaism, Christianity and Islam are indeed used throughout in the Grundriss article (together with Confucianism, Hinduism and Buddhism) to serve the comparative viewpoint, based on differences; in the Gesammelte Aufsätze zur Religionssoziologie, in contrast, they appear primarily in a developmental sequence. Compared with Asia, their internal differences fade into the background, however: the image of the divine that emphasizes the personal, supernatural creator God, not the eternal uncreated order; salvation that must be won through conduct willed by God, not through gnosis; the path to salvation that leads through actionism and asceticism, not contemplation and mysticism; the salvation-oriented organization that favours the formation of communities, not the individual masterdisciple relationship. By these differences - and they are not the only ones - the characteristics of Near-Eastern-Occidental development are defined with respect to Asiatic developments. Their expression, however, was also partly caused by those crucial turning points, that Weber cited at the beginning of his study on ancient Jewry. They determined the general direction of Israelite-Jewish-Christian religious development, which he summerized in the notion of disenchantment.

\section{The Old Testament as a "Crucial Turning Point" in the Total Cultural History of the Near East and the West}

Among these "crucial turning points" or "switch yards", Weber accords outstanding significance to the 'creations' of the Old Testament, the Bible of the Jews. This was, so to speak, the moment of the fundamental decision that later divided European and North American cultural developments from the rest, that of Islam included. These 'creations' are discussed in detail in the study on ancient Judaism. In this respect, they take on a key role for the portrayal of the special development of the Near-East and the Occident. In the study on ascetic Protestantism, Weber had come to comprehend the provisional end point of this great religious process of the disenchantment of the world. With the study on ancient Judaism, he now traces it back to its point of origin.

In this study too, Max Weber combines comparison and developmental history. He starts with an unusual comparison. He takes as an ideal type the Indian caste system, the ritual segregation of groups and their interconnection through division of labour - intermarriage and commensality no, commerce yes - and compares it with the position of Jewry, which he terms "a pariah people in a casteless environment" (42). At the same time, he emphasizes the differences that subsist with respect to the lowest Indian caste, the Pariahs. The emphasis is on self-isolation, the "voluntary ghetto existence" of the Jews compared to the imposed ghetto existence of the Indian Pariah caste. The promises of salvation also differ: while the Indian must perform the duties of his caste, with the prospect of individual promotion within the caste order in a future life, which in fact stabilizes the caste-system,

(42) RS III, p. 5. 
the Jewish people is promised a God-given political and social revolution, which will one day elevate it to the rank of master race. But above all, Weber sees ritual exclusion as no more than the external manifestation of an inner morality whose commands make the highest demands upon the believer. It is a religious ethic of rational innerworldly conduct which, as he says, "to a large extent still underlies the European and Middle-Eastern religious ethic of today (43)".

Weber takes his unconventional comparison between Indian religion and Judaism even further: thus he contrasts the Brahmins with the Levites, who represent disparate professional groups versed in ritual and the law. But he also contrasts Yahweh with Brahman (and the Tao), the thought of a personal, transcendent creator God with that of an uncreated, immanent and eternal order, which leads to different conceptions of transcendence.

But the hypothesis of voluntary ghetto existence and the resulting status of a pariah people is the primary aim of this comparison. I shall return to this hypothesis in the last part of my exposition. Before we come to that, it is more important to note that after his comparative introductory section, Weber changes over to developmental history. He is concerned with the religious 'creations', which in the end are decreed by that religious ethic of rational innerworldly conduct: the oldest collection, the Book of the Covenant, and the Decalogue, which can today be dated to about 1,000 to $800 \mathrm{BC}$; the Law of Deuteronomy, which presents a programme of reform for the period during and after the Exile, which probably originated about 550 to 500 , and the most recent collection, the sacred law and priests' codex, which are dated to about 500 to $400 \mathrm{BC}$. But what fascinated Weber above all was the prophetic books, especially Isaiah (including Deutero- and Trito-Isaiah), Jeremiah, Ezekiel and Amos (44) - and not forgetting the book of Job. But in the prophetic books, he saw the foundations of a sublimation based on an ethic of conviction, of the material put together in the collections, which leads to an ethic of law only (45).

Weber is imprecise in his dating, and of course dependent on the state of debate of his time. In his analysis, he only follows a very crude chronology (before, during, and after the Exile). Neither is the study strictly chronological, but is constructed in accordance with the important analytical viewpoints: it deals first with the socio-economic and socio-political situations in Syria and Palestine and their representation in law, especially the covenant with Yahweh and the constitution of the confederacy, its transformation into a monarchy, the north-south schism

(43) Ibid., p. 6.

(44) This arrangement in the canon does not correspond to the supposed historical sequence. After this comes first Amos (c. 780 to 750), then Isaiah (c. 740 to 700), then Jeremiah (c. 625 to 595), last Ezekiel (c. 600 to 570), who is already a prophet of the period of Exile. Deutero-Isaiah, the second Isaiah (Isa. 40-55), was already seen as a book in its own right and, as a later interpolation in the Book of Isaiah, dates its origin to the end of the period of Exile. Weber broadly adheres to these crude datings. Nevertheless, he does speak of the "pre-Exile prophets from Amos to Jeremiah and Ezekiel". Ibid., p. 281.

(45) The Torah numbered 613 rules, 248 commands and 365 prohibitions. To Weber's mind, this normative material forms the foundation of the prophecy. In his view, these rules from the "pre-Exile teaching of the Torah", the "Levite Torah", constitute the content of the Jewish ethic (ibid., pp. 250f.), though this did not deviate strikingly from the religious ethics of other peoples. Only with the prophecy did it become stamped with its specific characteristics: "the central religious conviction that lies behind it." Ibid., p. 333. 
(Judaea and Israel) and the exile in Persia (Babylon) and Egypt respectively. There follows a description of the conception of God and of worship, and of the bearers of a theologization of the law: the Levites. Next comes the presentation of the preexile prophetic message as part of a prophecy of doom, which favours an ethic of conviction, based on the canonized 'laws' systematized by the Levites. (At this point, Weber applies his general pronouncement about the relationship between priests, prophets and the laity from the chapter on religious communities in the Grundriss article to a historical case, continuing with the distinction between magic and a religious ethic, divine coercion and worship). Finally, the prophetic message of the Exile (and post-Exile) period is presented as prophecy of hope, especially the prophetic theodicy of suffering (Isa. 40-55) with eschatological features (46), formulated in Deutero-Isaiah, and the gradual transformation of the political community into a confessional one. The hypothesis: prophecy dies away step by step in the course of this process.

At the same time, Weber deals with important 'external' factors of tension too: little Israel is constantly under threat from the surrounding great powers; the hilly, fertile north provides living conditions different from the desert south; the settled farmers co-exist with difficulty with the pastoral nomads; the city, with its urbanbased patrician class stands in opposition to the country side. Weber depicts the Jewish people as culturally elevated and autonomous, but marked by the experience of collective menace: the experience of the irrationality of the world, which he is known to have considered the driving force behind all religion, takes the shape here primarily of the experience of political deprivation (exile, subjection, inner enslavement, the downfall of the northern kingdom, repeated exile). The creations of the Old Testament arose not least as a reaction to all this. They provide motivation for actively grappling with a situation threatening not only to the community but also the individual.

But why were they able to become a "crucial turning point", a "switch yard" of Middle-Eastern and Western development? Because they supported religious rationalization. Weber indeed determines the degree of rationalization that a religion has reached by reference to two yardsticks: in first place he takes the "extent to which it has rid itself of magic", and in the second place the "the extent of the systematic unity into which it has brought the relationship of God and the world and thence its own ethical stance towards the world (47)." When these two yardsticks are applied to Israelite-Jewish religious development, it is immediately plain that religious rationalization has progressed a long way in relative terms. The Levites in particular rationalized their worship in contrast to the esoteric Egyptian cult of the dead and the orgiastic cults of Baal in the north, thereby desacralizing the clan (yardstick 1); the prophetic message, however, sublimated Levite teaching of positive rituals and ethical commands into an ethical attitude, emphasizing the central significance of the ethical relationship of the people as a whole and of each individual to the world (yardstick 2). Weber summarizes his view as follows: Moses was indeed the originator of an important religio-ethical development. But only Levite

(46) Deutero-Isaiah is the first prophetic book to work out a theodicy, linked here to an eschatology. What is expressed here for the community is expressed in the Book of Job for the individual. Apocalyptic elements are also to be found in the book of Isaiah.

(47) RS I, p. 512 (MWG I/19, p. 450). 
rationalism in combination with the prophetic message was successful in stabilizing Israelite-Jewish religiousness "against any subversion from outside" (48); only this combination gave it the capacity to survive even in the face of the most unfavourable external circumstances. Certainly, this alone would not have been enough; self-ghettoization, a ritual and also real separation from the social environment, had to be added to it, especially as the fall of the second Temple brought with it the definitive destruction of the political confederacy.

\section{The (mis-)construction of a Jewish pariah people's situation from the Persian-Babylonian exile stage up to the fall of the second Temple}

This leads back to the hypothesis that Weber had derived from the India-Palestine comparison: can it be said that the assertion of voluntary ghetto existence, of a special position due to ritual separation, of the status of a pariah people in a casteless environment, is really true of ancient Jewry? There can be no question here of bringing counter-evidence to bear. This has been done frequently in the secondary literature (49); I am not historically competent for the task. What I find much more interesting is to look behind Weber's construction. What was his motivation for it?

The most striking feature is that Weber depicts the process during and after the Persian-Babylonian exile, from a cultural viewpoint, as a constant narrowing of spiritual horizons: the ritual rules move into the foreground relative to the legal and ethical commands, the prophetic message is transformed from a prophecy of doom to a prophecy of hope, and in the end is completely stifled by a theocracy laying hands on everything around it. Thus the cultural narrowing goes hand in hand with an institutional fossilization. Movements in favour of renewal within Jewry are opposed, some stifled, some pushed to the periphery, like the Essenes, for example (Weber could of course have known nothing of Qumran.) (50) Jewry formed itself into an association that was internally homogenous, but externally insular.

Max Weber - like every reader of the New Testament - knew that even if we consider only the descriptions of the religious conflicts to be found in the history of the apostles, written about $90 \mathrm{AD}$, we find a strange contrast with this construction of inward and outward fossilization. The Jesus movement is after all first and foremost an internal Jewish movement for renewal, and as it becomes increasingly independent, the inner Jewish conflicts persist, and even gain in strength. Sadducees and Pharisees dispute the role of the Resurrection and the Spirit; the strict Jewry of Jerusalem fights against the lax Jewry of the Diaspora; Jewish and Gentile

(48) $R S$ III, p. 280.

(49) Examples of this can be found in Wolfgang Schluchter, ed., Max Webers Studien über das antike Judentum, Frankfurt, Suhrkamp 1981.

(50) There is much argument as to whether the Qumran community (sect) and the Essenes were one and the same. This question I leave open. Whatever the truth of the matter, the texts from Qumran reveal a Jewish apocalyptic movement which displays great similarities with certain currents in early Christianity. 
Christians argue about the role of circumcision, and even of the Jewish ritual prescriptions in general. One gains the impression of a conflict-laden religious pluralism within Jewry and on its periphery, not to mention the conflicts with Greek and Roman tradition in which both Jews and Christians are becoming entangled (51). Weber himself speaks of a "profusion of cults, schools, sects and orders of every kind" characterizing not only Asia, but also the ancient Occident, a religious pluralism restrained only by 'reasons of state', where it did finally meet an inflexible limit (52). In the fragment on the Pharisees, Weber again underlines this religious diversity (53). None of this tallies with the picture of cultural and social rigidity. What led Weber, so knowledgeable about Antiquity, to this perception (54)?

We might first answer: this perception arises as a back-projection of mediaeval conditions on to antiquity (the ghetto), and a post-Reformation concept (confessional community) is inappropriately applied. Yet in my view, this too is only half the truth. There is a more profound reason for the (mis-)construction. Weber paints a background against which the Pauline mission stands out in a clear light. He sees this as an act of liberation of world-historical significance. It was this above all that preserved the creations of the Old Testament for early Christianity as it freed itself from the imposition of Jewish modes of thought. For, as Weber puts it: "Among the most important spiritual achievements of the Pauline mission was that it kept this holy book of the Jews alive to become a holy book of the Christian religion; at the same time, it eliminated all those ethical features taught in it, which specifically anchored the Jews ritually in their characteristic state of a pariah people, as no longer obligatory, having been annulled by the Christian liberator (55)." Without this construction of the status of a pariah people, the act of liberation would not be quite so spectacular.

It is a fact that Weber sees a turning point for further development in the disagreement between Peter and Paul, to whom the company of the apostles had entrusted responsibility for the mission to the Jews and the Gentiles respectively. For as represented by Paul in the Epistle to the Galatians, dated c. 54 AD, not only he but also Peter ate at the same table with Gentiles, though the latter denies this to the Jews, which Paul sharply admonishes (Gal. 2, 11-21). In the challenge that was

(51) Belief in the Resurrection and in an eschatological renewal of the world, which dominated early Christianity and the apocalyptic tendencies in Jewry, were foreign to Greek thought. Concerning the dispute that arose from this during Paul's stay in Athens, Acts 17, 16.

(52) $R S$ II, p. 364 (MWG I/20, p. 527).

(53) On this subject, see the essays in Wolfgang Schluchter, ed., Max Webers Sicht des antiken Christentums, Frankfurt, Suhrkamp 1985.

(54) Of course, this picture is not complete invention. Because of its laws, which were "diverse from all people" and bound up with its separation, anti-Judaism was already existent in antiquity, going hand in hand with acts of violence against the scattered Jewish communities. An example of this can be seen in Esther 3, p. 15.

(55) RS III, p. $6 f$. But it should not be forgotten that the opposition between universalism and particularism was among the fundamental tensions present in post-exile Jewry, and that there were definite tendencies, not least under Hellenistic influence, towards a world-religious understanding of Jewry, including proselytism. Weber was fully aware of this, but considered - probably with justice - that the opposing trend was the stronger. The peak period for the world-religious orientation seems to have been during the second century $\mathrm{BC}$, at the time of the re-establishment of the temple cult in Jerusalem by Judas Maccabaeus and the regaining of political freedom, though the latter only lasted a short time and was not liberating either. (Jerusalem was to fall under Roman rule in 69 BC.). It was a period in which a vigorous Diaspora Jewry also developed. 
bound up with this, of breaking through ritual barriers, Weber saw an urge towards universalization, which he calls the hour of conception of occidental citizenship. For "without this emancipation from the ritual, compartmentalized separation of the Jews, founded on the prescriptions of the Torah... the Christian community would have remained, just like the Essenes and the Therapeuts, for example, merely a small sect within the Jewish pariah people (56)."

It is clear enough that Weber is adhering to a dramatic conception that brings the world-historical role of Paul to the fore. But it can also be seen that between ancient Jewish prophecy and ascetic Protestantism there are developmental links which, in the right circumstances, can lead to fundamental changes of direction. The development process does indeed take a long time, but is not inevitable. Again and again, it is necessary to invent, and from time to time to re-invent. I close with a quotation that I find particularly impressive: hardly ever, says Weber, "have totally new religious concepts arisen in the centres of any of the rational cultures. Not in Babylon, Athens, Alexandria, Rome, Paris, London, Cologne, Hamburg or Vienna, but in the Jerusalem of the pre-Exile period, in the Galilee of the late Jewish period, in the late Roman province of Africa, in Assisi, in Wittenberg, Zurich, Geneva and in the outer zones of the Dutch-North German and English cultures, such as Friesland and New England, have new rational prophetic or reformatory entities first been conceived. The reason is everywhere one and the same: new conceptions of a religious nature can only arise where man has not forgotten how to face up to event in the world with his own questions. And it is precisely the man who lives far away from the great cultural centres who has occasion to do so, when their influence begins to affect him in his central interests and to become a threat (57)." This can also be formulated in the abstract: economics and sociology are only able to develop into social sciences as cultural sciences when they are rooted in a theory of human action which does not assimilate human creativity to mere utility.

Wolfgang SCHLUCHTER University of Heidelberg 


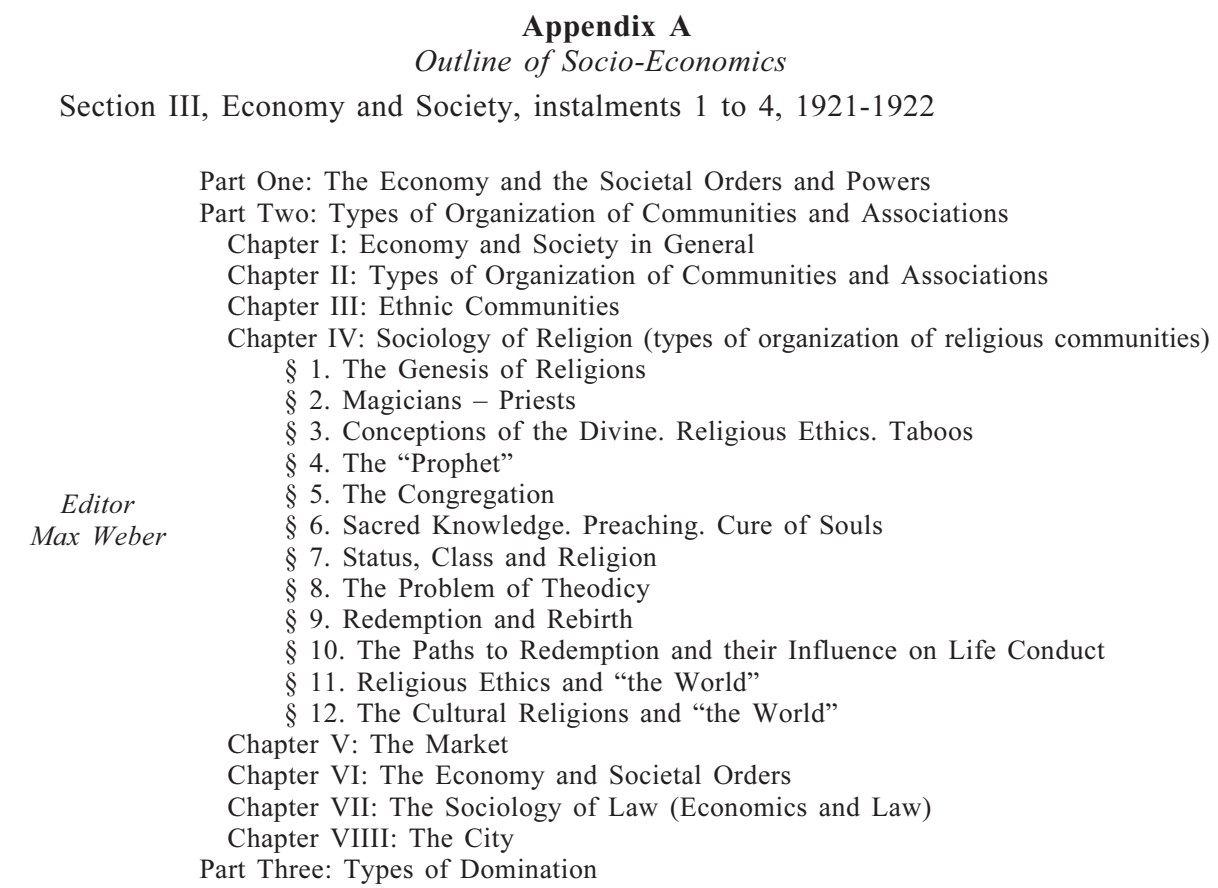




\section{Appendix B \\ Max Weber: Collected Essays on the Sociology of Religion \\ (Plan dated 1919 and its execution)}

\section{Volume 1}

Submitted for printing by Max Weber. Layout reviewed by Marianne Weber (correction of page headings of "Intermediate Reflection" by her)

I. The Protestant Ethic and the Spirit of Capitalism

1904-1905,

I. The Problem

revised 1920

II. The Work Ethic of Ascetic Protestantism

II. The Protestant Sects and the Spirit of Capitalism

III. The Economic Ethics of World Religions

1906 (two versions), revised 1920 Introduction

1915 ,

revised 1920

I. Confucianism and Taoism

1915

I. Sociological Foundations:

revised 1920

A. City, Prince and God

II. Sociological Foundations:

B. Feudal and Prebendal States

III. Sociological Foundations:

C. Administration and Agrarian Conditions

IV. Sociological Foundations:

D. Self Government, Law and Capitalism

V. The Literati

VI. The Confucian Orientation to Life

VII. Orthodoxy and Heterodoxy - (Taoism)

VIII. Result: Confucianism and Puritanism

Intermediate Reflection: Theory of Stages and Directions in

1915 revised 1920

1916-1917

1920 republished (intended revision not carried out) 


\section{Volume 2}

The General Foundations of Occidental Development (and/or: the Development of European Citizenship in Antiquity and the Middle Ages)

News bulletin of the publishers dated 25th Oct. 1919 , p. 11

Egyptian, Babylonian and Persian Relations (or: Egyptian, Mesopotamian and Zarathustran Religious Ethic(s)

Archives,

vol. 44 , booklet 1 , Oct. 1917, p. 52 and News

Ancient Judaism

I. The Israelite Confederacy and Yahweh

1917-1920,

II. The Origin of the Jewish Pariah People

1920 republished

(intended revision not carried out)

Supplement: Psalms and the Book of Job

Preface $R S$ III

Appendix: The Pharisees (intellectual estate)

Preface RS III and News

\section{Volume 3}

Talmudic Judaism

Early Christianity

Oriental Christianity

Islam

\section{Volume 4}

The Christianity of the West

News

$=$ planned but never carried out.

"The subject throughout is the treatment of the question: on what the social and economic uniqueness of the West is founded, how it arose and especially in what relation it stands to the development of religious News ethics." 


\section{Appendix C}

Table of Contents (as designed by Max Weber)

\section{Volume I}

Preliminary Remarks

The Protestant Ethic and the Spirit of Capitalism

I. The Problem

1. Religious Affiliation and Social Stratification 17.- 2. The "Spirit" of Capitalism 30.- 3. Luther's Concept of Vocation.- The Purpose of the Investigation 63.

II. The Work Ethic of Ascetic Protestantism

1. The Religious Foundations of Inner Asceticism 84.-

2. Asceticism and the Capitalist Mind 163.

The Protestant Sects and the Spirit of Capitalism

I. Sociological Foundations: A. City, Prince and God 276.-

II. Sociological Foundations: B. Feudal and Prebendary States 314.-

III. Basic Concepts in Sociology: C. Administration and Agrarian Constitution 349.- IV. Sociological Foundations: D. Self-Determination, Law, and Capitalism 373.- V. The Literati 395.-

VI. The Confucian Approach to Life 430.- VII. Orthodoxy and Heterodoxy (Taoism) 458.- VIII. Result: Confucianism and Puritanism 512.

Intermediate Analysis: Theory of the Stages and Directions of Religious Abnegation of the World

The Meaning of a Rational Construction of the Motives forAbnegation of the World 537.- Typology of Asceticism and Mysticism 538.- Directions of Abnegation of the World: Economic, Aesthetic, Erotic, and Intellectual Spheres 542.Stages in Abnegation of the World 567.- The Three Rational Forms of Theodicy 571. 


\section{Appendix C}

Contents (as published by Marianne Weber)

Preliminary Remarks

The Protestant Ethic and the Spirit of Capitalism

I. The Problem

1. Religious Affiliation and Social Stratification 17. -

2. The "Spirit" of Capitalism 30.-

3. Luther's Concept of Vocation.

The Purpose of the Investigation 63.

II. The Work Ethic of Ascetic Protestantism

1. The Religious Foundations of Inner Asceticism 84. -

Asceticism and the Capitalist Mind 163

The Protestant Sects and the Spirit of Capitalism

Vol. I

The Economic Ethics of World Religions

Introduction

I. Confucianism and Taoism

I. Basic Concepts in Sociology: A. City, Prince and God

276. - II. Basic Concepts in Sociology: B. Feudal and

Prebendary States 314. - III. Basic Concepts in Sociology:

C. Administration and Agrarian Constitution 349. - IV.

Basic Concepts in Sociology: D. Self-Determination, Law

and Capitalism 373. - V. The Literary Class 395. - VI.

The Confucian Approach to Life 430. - VII. Orthodoxy

and Heterodoxy. - (Taoism) 458. - VIII. Result: Confucianism and

Puritanism 512.

Intermediate Analysis: Theory of the Stages and Directions of Religious Abnegation of the World.

The Meaning of a Rational Construction of the Motives for Abnegation of the World 537. - Typology of Asceticism and Mysticism 538. - Directions of Abnegation of the World: Economic, Aesthetic, Erotic and Intellectual Spheres 542. - Stages in Abnegation of the World 567. The Three Rational Forms of Theodicy 571.

Vol. II | II. Hinduism and Buddhism.

I. The Hindu Social System. - II. The Heterogeneous and Heterodox Redemption Teachings of the Indian Intellectuals. - III. The Asiatic Sects and the Religiosity of Salvation. -

Vol. III III. Ancient Judaism.

I. The Israelite Confederacy and Yahweh. - II. The Origin of the Jewish Pariah People. - Appendix: The Pharisees
Page

$1-16$

$17-206$

17-83 1904/05

revised

1920

84-206

207-236 1906 2x revised

1920

237-275 1915,

276-536 revised 1920

536-573 1915

revised

1920 


\section{Abstract}

Max Weber's approach to the sociology of religion still poses a puzzle. Difficult logical-methodical and substantive issues are involved. As it is well known, he first dealt with religion in 1904/1905, in his essay on the relationship between ascetic Protestantism and the emerging 'spirit' of modern capitalism, which he regarded a study in the history of religion, confined to the post-Reformation period. From 1910 onward, however, step by step he expanded his approach in scope and analytical complexity. Now he tried to cover all major religions in the Mediterranean-European and Asian areas. This project, which was to be realized in four volumes, aimed at identifying the distinctiveness of the European and American, i.e. Western, modern rationalism and at explaining its emergence, especially from a religious-ethical viewpoint. It is linked to another major project, his Grundriss article, known as Economy and Society. Both projects are complementary, but do not mature simultaneously. In the present article it is shown, how they remained interconnected and how Weber established through them his comparative and developmental-historical perspectives. It is also demonstrated, how he put his early study on ascetic Protestantism into context by connecting it with his later study on ancient Judaism.

\section{Résumé}

La sociologie de la religion de Max Weber continue de poser une énigme. Des questions difficiles de logique et de méthode, tout comme des problèmes de fond sont impliqués. Comme on le sait, Weber s'est d'abord intéressé à la religion en 1904/05 dans un essai portant sur le rapport entre le protestantisme ascétique et "l'esprit 》 naissant du capitalisme moderne, essai qu'il considérait comme une étude de l'histoire de la religion, confinée à la période post-réforme. A partir de 1910 cependant, il a petit à petit élargi son approche à la fois du point de vue des domaines abordés et de la complexité analytique. Il a tenté, dès lors, d'aborder toutes les grandes religions des zones méditerranéenne-européenne et asiatique. Ce projet, couvrant quatre volumes, visait à identifier le caractère distinctif du rationalisme européen et américain, c'est-à-dire occidental, et à expliquer son apparition, en particulier d'un point de vue religio-éthique. Il était lié à un autre projet majeur, son article Economie et Société. Les deux projets sont complémentaires, mais n'ont pas été développés simultanément. Dans cet article on tente de montrer leur inter-relation et la façon dont Weber a, à travers ces deux projets, fondé ses perspectives comparative et historico-évolutive. On y montre aussi comment il a contextualisé sa première étude sur le protestantisme ascétique en la reliant à son étude ultérieure sur le judaïsme ancien.

\section{Resumen}

La sociología de la religión de Max Weber continua planteando un enigma. Se mezclan aquí preguntas difíciles de lógica y de método, asi como problemas de fondo. Como es sabido, él se interesó en principio en la religión en 1904-1905, en un ensayo sobre la relación entre el protestantismo ascético y el "espíritu" naciente del capitalismo moderno, ensayo que él consideraba como un estudio de la historia de la religión, confinado al período post-reforma. A partir de 1910 sin embargo, poco a poco Weber amplía su perspectiva a la vez desde el punto de vista de los temas abordados y de la complejidad analitica. Él intentó, desde entonces, abordar todas las principales religiones de la zona mediterránea-europea y asiática. Este proyecto, que abarca cuatro volúmenes, tenía el objetivo de identificar el carácter distintivo del racionalismo europeo y americano, es decir occidental, y de explicar su aparición, en particular desde el punto de vista ético-religioso. Estaba ligado a otro proyecto mayor, su artículo Economía y Sociedad. Los dos proyectos son complementarios, pero no fueron desarrollados simultáneamente. En este artículo tratamos de mostrar su interrelación y la manera en que Weber, ha, a través de estos dos proyectos, fundado sus perspectivas comparativa e histórico-evolutiva. Mostramos también como ha contextualizado su primer estudio sobre el protestantismo ascético asociándolo a su estudio ulterior sobre el judaísmo antiguo. 